\title{
Farmers' Access to ICT Based Media in Receiving Farm Information: A Grassroots Level Study from Bangladesh
}

\author{
Abdul Khalak, M Asaduzzaman Sarker*, M Nasir Uddin \\ Department of Agricultural Extension Education, Bangladesh Agricultural, Mymensingh, Bangladesh \\ *Corresponding author: masarker@bau.edu.bd
}

\begin{abstract}
Information is one of the vital factors of production while ICT to provide efficient and effective information. Thus, the study was undertaken mainly to determine farmers' extent of access to ICT based media in receiving agricultural information. Besides, important factors associated with farmers' extent of access to ICT based media were also explored. The study was conducted at Fulbaria upazila (sub-district) under Mymensingh district in Bangladesh. Eighty (80) farmers were interviewed using structured questionnaire to collect the data. Both descriptive and inferential statistical analysis were used to interpret the trend and tendencies of collected data. The findings of the study revealed that the majority ( 81.2 percent) of the respondents had low access to ICT while only 3.8 percent had medium access and 15.0 percent of them having no access to ICT based media. The step-wise multiple regression results explored that availability of ICTs, knowledge on ICT and training received on ICTs were identified as influential factors in case of increasing the extent of farmers' access to ICT based media. Lack of operational knowledge of computer, poor level of education, lack of training facilities on ICT, insufficient numbers of ICT centre, poor knowledge on the availability of ICT based facilities, lack of personal interest were identified as the major constraints faced by the farmers to access to ICTs based media.
\end{abstract}

Keywords: access, ICT media, agricultural information, farmers and Bangladesh

Cite This Article: Abdul Khalak, M Asaduzzaman Sarker, and M Nasir Uddin, "Farmers' Access to ICT Based Media in Receiving Farm Information: A Grassroots Level Study from Bangladesh.” American Journal of Rural Development, vol. 6, no. 1 (2018): 14-20. doi: 10.12691/ajrd-6-1-3.

\section{Introduction}

Bangladesh is mainly an agro-based country and agriculture is crucial to the livelihoods of millions of Bangladeshi. Agriculture sector contributes 15.96 percent of its GDP and 80 percent of its employment opportunity [1]. However, there are many challenges to agriculture like declining soil fertility, poor access to quality inputs and extension services and access to equitable markets [2]. Traditionally, agricultural extension service providers were the main sources of credible information to the majority of the Bangladeshi farmers [3]. However, in recent time agricultural extension in the country provides critical access to the knowledge, information and technology that farmers importantly needed to improve the productivity and thus improve the quality of their lives and livelihoods [4]. It is also proved by the findings of other researchers that access, efficiency and affordability of agricultural information are the major barriers in the battle to uplift agricultural productivity among smallholder farmers [5]. While information and communication technologies (ICTs) are playing a pivotal role in disseminating agricultural and even non-agricultural information in rural Bangladesh [6]. ICT based media is defined by the scientist as an umbrella term that includes computer hardware and software, digital broadcast and telecommunication technologies as well as digital information depositories either online or offline, and contemporary social networking aspects, read/write interfaces on the web besides file sharing systems online [7]. It also includes wide range of elements like TV, radio, cell phones and policies and laws that govern the widespread use of these media. ICTs can bridge the communication gaps among development workers, rural organizations and farmers. It can also enable bottom up articulation of needs and information sharing of local knowledge and enhance research-extension-farmer linkage and improve the quality decisions that affect rural communities as well as agricultural and rural development [8]. The history of ICT uses in the agriculture sector of Bangladesh is not so rich. Information and Communication Centre (AICC) was established in the country during 2009-2010 with the view of faster delivery of farm information to the people of the farming community. There are 245 AICCs in the country those providing services like weather information, crop cultivation techniques, disease and insect information and latest price information to $40-50$ famers per day which is not really sufficient [9]. However, the cost factor in faceto-face information dissemination at the right time , and the difficulties in reaching the target audiences, has also created the urgency of introducing ICT based media in agricultural technology transfer [10]. Considering these realities the present study was undertaken to assess the level of access of the farmers to ICT based media for receiving agricultural information and to explore the factors responsible to affect farmers' access to ICT based media. 


\section{Conceptual Framework}

Research-extension-farmer linkage is very important for proper flow of information to solve the day to day farming problems of the farmers and to bring about the desirable change in their livelihoods. However, the lack of close working relations between national agricultural research and extension organizations, and with different types of farmers and their organizations, is one of the most difficult institutional problems leading to slowing down agricultural growth in many developing nations [11]. There are two types of technology like, i) Material technology and ii) knowledge-based technology which is for the application of knowledge for practical purposes and is used to improve the human capabilities, quality of natural environment, or to carry out other socio-economic activities.

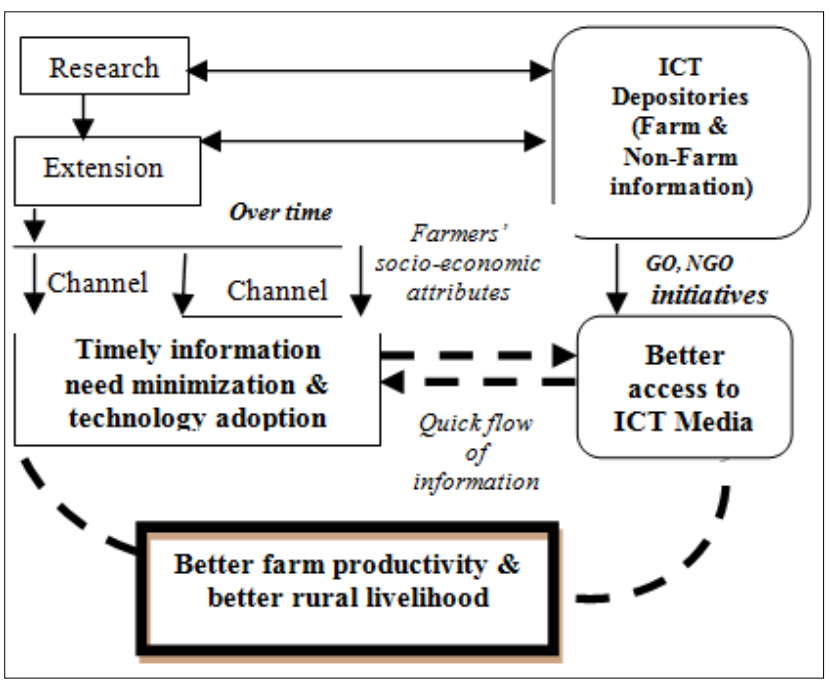

Figure 1. Conceptual framework of the study

In technology transfer process it is a bit easier to transfer of material technology than training and disseminating technical knowledge and management skill to large number of poorly educated farmers. Conversely, the transfer process of knowledge-based technologies like improved crop or livestock production, IPM, INM practices are generally taught through training programs for rural youth, rural women and adult farmers supported by public extension system. Therefore, material and knowledgebased technologies are closely intertwined. NGOs and private sector firms in developing countries have very limited technical capacity to train farmers in these product related skills and knowledge; therefore, most knowledge based technologies is, by design or by default, left to national extension system. In Bangladesh the ratio between extension worker and farm families is 1: 1000 which is really huge to provide material and knowledge-based technologies to the farmers on time [12]. In the era of globalization ICT has become most powerful tool in providing developing countries with varied opportunities to meet vital development goals which includes poverty reduction far more effective than before [13]. According to Meera, ICT in extension can lead to the emergence of knowledge of the workers that will result in the realization of a bottom-up, demand-driven paradigm for technology generation, assessment, refinement and transfer [14]. It is strong belief of many researchers like Madukwe that ICT may be the panacea to problems of accessing variety of information sources that are affordable, relevant and reliable by the farmers [15]. Thus the above mentioned conceptual model it has been shown that it is demand of time to create sufficient access of the farmers to ICT based media.

\section{Methodology}

The study was conducted in two purposively selected villages namely Patria and Horbarin of Kaladaha union of Fulbaria upazila under Mymensingh district.

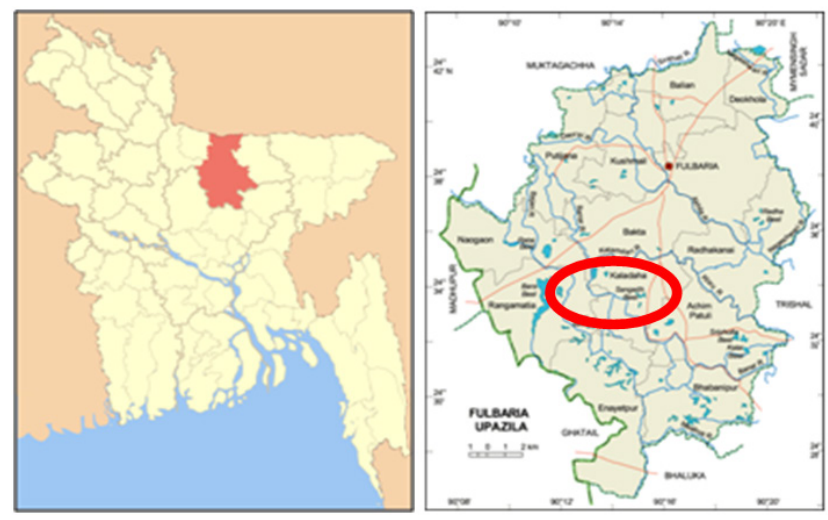

Figure 2. Map of the study area (red circled)

These two villages are fully agrarian and have Agricultural Information and Communication Centre (AICC) and thus the people of these villages are familiar with the ICT based media. For this reason these two villages were purposively selected for present study.

The total numbers of the farm families in the selected villages were 400 . Thus, 400 farm families from the selected villages were the population of the study. A detail of population and sampling of the study are shown in below.

\begin{tabular}{|c|c|c|c|c|}
\hline Sub-district & Union & Village & $\begin{array}{c}\text { No. of farm } \\
\text { families }\end{array}$ & $\begin{array}{c}\text { No. of sample } \\
\text { selected }\end{array}$ \\
\hline \multirow{2}{*}{ Fulbaria } & \multirow{3}{*}{ Kaladaha } & Patria & 175 & 35 \\
\cline { 3 - 5 } & & Horbarin & 225 & 45 \\
\cline { 3 - 5 } & & Total & $\mathrm{N}=400$ & $\mathrm{n}=80$ \\
\hline
\end{tabular}

About 20 percent of the farmers were selected as sample and finally a total of 80 farm families from two villages were the sample of the study. A complete list of the farm families of the selected two villages were collected from local extension worker and from this list 80 farmers were selected following simple random sampling method. Empirical data were collected using a pre-tested and structured questionnaire by face-to-face interviewing during September to October, 2016.

Extent of access to ICT based media of the farmers was the focus variable of the study. Therefore, the overall access to ICT based media of the farmers was measured on the basis the overall extent of access of the farmers into 9 different ICT based media for receiving agricultural information. Thus, the extent of access to ICT based 
media of a farmer was measured on the basis of his or her opinion given by them according to their extent of access to nine (9) ICT based medias of different nature. A 4-point rating scale was used in this regard where these were indicated as no, low, medium and Then, the extent of access scores of a respondent for the nine (9) ICT based medias were complied together to ascertain his/her total score for access to ICT based media for getting agricultural information. Thus, the extent of access to ICT based media of a farmer could ranged between 0 to 27, where 0 indicating no extent of access to ICT based media and 27 indicating the highest extent of access of a farmer to ICT based media for getting agricultural information.

SPSS v16 software was used to analyze the data. Both descriptive and inferential analyses were used to analyze the collected data. A co-efficient of correlation was used to show the trend of relationship between explanatory variables and focus variable of the study. However, stepwise multiple regression analysis was used to explore the important factors affecting the extent of farmers' access to ICT based media.

\section{Results and Discussion}

Characteristics profile of the respondent farmers includes age, education, household size, farm size, annual family income, organizational participation, farming experience, knowledge on ICT, training received on ICT and availability of ICTs have presented in Table 1. It is revealed from Table 1 that the majority of the farmers were middle aged category with an average of 43.26 . While their mean education level was 7.33 which is really better in the study villages compared to other villages of the sub-district.

It is also revealed from Table 1 that the farmers had medium size (5.52) household. However, the mean farm size of the respondent farmers were 0.95 ha which indicates that majority of them were small holders.

Table 1. Salient features of respondent farmers $(n=80)$

\begin{tabular}{|c|c|c|c|c|c|}
\hline \multirow{2}{*}{ Characteristics } & \multirow{2}{*}{$\begin{array}{l}\text { Scoring } \\
\text { system }\end{array}$} & \multicolumn{2}{|c|}{ Range } & \multirow{2}{*}{ Mean } & \multirow{2}{*}{$\mathrm{SD}^{*}$} \\
\hline & & Possible & Observed & & \\
\hline Age & Years & Unknown & $25-65$ & 43.26 & 8.41 \\
\hline Education & $\begin{array}{c}\text { Years of } \\
\text { schooling }\end{array}$ & Unknown & $0-18$ & 7.33 & 3.94 \\
\hline Household size & $\begin{array}{l}\text { Number of } \\
\text { members }\end{array}$ & Unknown & $2-10$ & 5.52 & 1.80 \\
\hline Farm size & Hectares & Unknown & $0.24-3.26$ & 0.95 & 0.66 \\
\hline $\begin{array}{l}\text { Annual family } \\
\text { income }\end{array}$ & ‘000’ BDT & Unknown & $35-318$ & 113.3 & 60.16 \\
\hline $\begin{array}{l}\text { Organizational } \\
\text { participation }\end{array}$ & Scale score & $0-14$ & $0-10$ & 2.95 & 2.01 \\
\hline Farming experience & Scale score & Unknown & $5-45$ & 24.28 & 8.70 \\
\hline Knowledge on ICT & Scale score & $0-20$ & $2-16$ & 7.01 & 3.22 \\
\hline $\begin{array}{c}\text { Availability of ICT } \\
\text { media }\end{array}$ & Scale score & $0-9$ & $1-8$ & 3.47 & 1.62 \\
\hline
\end{tabular}

$* \mathrm{SD}=$ Standard Deviation.

On the other hand, their annual income farming experience were moderate and it was 113.3 thousand BDT and 24.28 years respectively. While mean organization participation score was poor (2.95) compared to highest organization score (10). However, though the mean availability of ICT based media score in the study area was poor (3.47) but their average knowledge on ICT score was medium (7.01). This is may be due to the activities of Agricultural Information and Communication Centre (AICC).

\subsection{Farmers' Extent of Access to ICT Based Media in Receiving Agricultural Information}

On the basis of their access to ICT scores, the farmers were classified into four categories as shown in Table 2. Data presented in Table 2 indicates that the majority $(81.2 \%)$ of the respondent had limited access to ICT media while only $3.8 \%$ of them had medium access and $15 \%$ of them had no access to ICT based media.

This is due to the reason that the two AICC in two villages is not enough for creating sufficient access of the of the all farmers into ICT based media as the other medias like smart phone, internet facilities and television were very few in numbers.

Table 2. Extent of Access of the farmers to ICT based media in receiving agricultural Information

\begin{tabular}{|l|c|c|c|c|}
\hline \multirow{2}{*}{ Category of farmers } & \multicolumn{2}{|c|}{ Respondents $(\mathrm{n}=80)$} & \multirow{2}{*}{ Mean } & \multirow{2}{*}{ SD } \\
\cline { 2 - 3 } & Number & Percent & & \\
\hline Not at all $(0)$ & 12 & 15 & & \\
\cline { 1 - 3 } Limited access (1-9) & 65 & 81.2 & \multirow{2}{*}{3.38} & \multirow{2}{*}{2.53} \\
\cline { 1 - 3 } Moderate access (10-18) & 3 & 3.8 & & \\
\hline Adequate access $(>18)$ & 0 & 0 & & \\
\hline Total & 80 & 100 & & \\
\hline
\end{tabular}

\subsection{Farmers' Access to Different ICT Based Media}

There were 9 selected ICT based media included in the interview schedule and were asked to the respondent farmers to give their responses regarding their access to those media for receiving and providing agricultural information. Their responses were recorded and presented in Table 3. Data presented in Table 3 indicates the frustrating scenario that none of them had adequate access to any of the selected ICT media. Findings revealed that half of the farmers $(50 \%)$ had limited access to cell phone for getting agricultural information and still a significant portion (18\%) do not have access to cell phone. However, around one-third $(31 \%)$ of them had moderate access to cell phone which is relatively better compared to other ICT based media. This is due to the reason that they can to afford it to some extent. On the other hand, scenario of farmers' access to smart phone was quite different. Highest majority (84\%) of the farmers do not have access to smart phone. However, in the case of FM radio it was a bit better compared to smart phone and more than onethird $(38 \%)$ of the farmers had limited access to FM radio. It was similar to smart phone that only $4 \%$ of them had moderate access to FM radio and still more than half (59\%) of them do not have any access to FM radio. 
Table 3. Farmers' access to different ICT based media

\begin{tabular}{|l|c|c|c|c|}
\hline \multirow{2}{*}{ ICT based media } & \multicolumn{4}{|c|}{ Farmers' extent of access(n=80) } \\
\cline { 2 - 5 } & $\begin{array}{c}\text { Adequate } \\
\text { access }\end{array}$ & $\begin{array}{c}\text { Moderate } \\
\text { access }\end{array}$ & $\begin{array}{c}\text { Limited } \\
\text { access }\end{array}$ & Not at all \\
\hline 1. Cell phone & $0(0)$ & $25(31.25)$ & $40(50.0)$ & $15(18.75)$ \\
\hline 2. Smartphone & $0(0)$ & $3(3.75)$ & $10(12.5)$ & $67(83.75)$ \\
\hline 3. FM radio & $0(0)$ & $3(3.75)$ & $30(37.5)$ & $47(58.75)$ \\
\hline 4. Television & $0(0)$ & $21(26.25)$ & $33(41.25)$ & $26(32.5)$ \\
\hline $\begin{array}{l}\text { 5. Personal } \\
\text { Computer (desktop } \\
\text { \& laptop) }\end{array}$ & $0(0)$ & $0(0)$ & $3(3.75)$ & $77(96.25)$ \\
\hline 6. Internet & $0(0)$ & $1(1.25)$ & $7(8.75)$ & $72(90.0)$ \\
\hline $\begin{array}{l}\text { 7. Free internet } \\
\text { facilities }\end{array}$ & $0(0)$ & $4(5.0)$ & $31(38.75)$ & $45(56.25)$ \\
\hline 8. FaceBook & $0(0)$ & $1(1.25)$ & $4(5.0)$ & $75(93.75)$ \\
\hline 9. E-mail & $0(0)$ & $0(0)$ & $0(0)$ & $0(0)$ \\
\hline
\end{tabular}

[Number in the parentheses indicate percentage of the farmers].
Mean while, television viewing has been increased in the rural Bangladesh and it was reflected in Table 3 that around two-third $(68 \%)$ of the farmers had limited to moderate access to television. While more than $90 \%$ of the farmers do not have and personal computer and personal internet facilities. Nevertheless, a significant portion of them $(43 \%)$ are enjoying free internet facilities provided by AICC. Among them $39 \%$ of them had limited access and rest $5 \%$ had moderate access to such free internet services. On the other hand, absolute majority (94\%) of the farmers do not have access to social network like FaceBook and all of them do not have any access to e-mail.

Additionally it was tried to make a rank order of the nine selected media according to the extent of access of the farmers on those and shown in Figure 3. Figure 3 also revealed that among the nine selected ICT media farmers had highest access to cell phone and it was ranked $1^{\text {st }}$ among all ICT media for getting agricultural information. Next to cell phone television, free internet facilities and FM radio ranked $2^{\text {nd }}, 3^{\text {rd }}$ and $4^{\text {th }}$ position respectively.

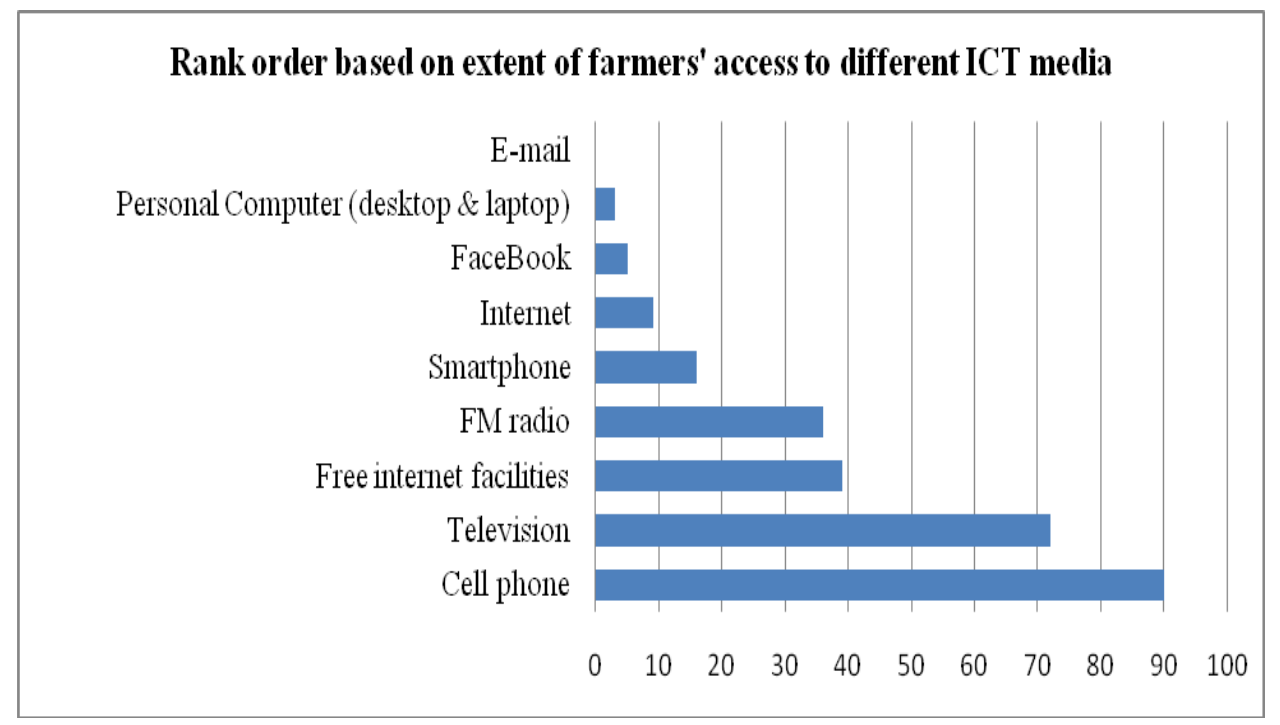

Figure 3. Rank order of different ICT media based on farmers' extent of access

While it was demonstrated that farmers did not have any access to e-mail and least of them had access was to personal computer.

\subsection{Relationship between the Selected Characteristics of the Farmers' and Their Access to ICT based Media in Receiving Agricultural Information}

The relationship between the selected characteristics of the farmers and their access to ICT based media in receiving agricultural information was measured using Pearson's product moment correlation analysis and the results were presented in Table 4.

The findings of the study indicates that education, organizational participation, knowledge on ICT, training received on ICT and availability of ICTs had positive and significant relationships with farmers' access to ICT based media at $1 \%$ level of significance.

However, age of the farmers and farming experience had shown significant and negative relationship with their access to ICT based media. Similar results were found by
Asif [16]. This is may be due to the reason that young people are always interested to ICTs compared to old farmers.

Table 4. Relationship between the selected characteristics of the farmers and their use of ICT based media in receiving agricultural information $(\mathbf{n}=\mathbf{8 0})$

\begin{tabular}{|c|c|c|c|}
\hline \multirow{2}{*}{$\begin{array}{c}\text { Selected personal } \\
\text { socioeconomic characteristics }\end{array}$} & \multirow{2}{*}{$\begin{array}{l}\text { Correlation } \\
\text { co-efficient (r) } \\
\text { with } 78 \mathrm{df}\end{array}$} & \multicolumn{2}{|c|}{$\begin{array}{c}\text { Table values (r) } \\
\text { with } 78 \mathrm{df}\end{array}$} \\
\hline & & $\begin{array}{l}\text { Sig. at } \\
0.05\end{array}$ & $\begin{array}{l}\text { Sig. at } \\
0.01\end{array}$ \\
\hline Age & $-.335 * *$ & \multirow{10}{*}{0.250} & \multirow{10}{*}{0.325} \\
\hline Education & $.464 * *$ & & \\
\hline Household size & -.039 & & \\
\hline Farm size & .123 & & \\
\hline Annual family income & .125 & & \\
\hline Organizational participation & $.383 * *$ & & \\
\hline Farming experience & $-.379 * *$ & & \\
\hline Knowledge on ICT & $.758 * *$ & & \\
\hline Training received on ICT & $.501 * *$ & & \\
\hline Availability of ICTs & $.789 * *$ & & \\
\hline
\end{tabular}

* Correlation is significant at the 0.05 level (2-tailed). ** Correlation is significant at the 0.01 level (2-tailed). 


\subsection{Factors Associated with Farmers' Extent of Access to ICT Based Media}

To explore the factors associated with farmers' extent of access to ICT based media in receiving agricultural information multiple regression analysis (enter method) was performed. The findings of the regression analysis are presented in Table 5.

The value of adjusted $\mathrm{R}^{2}$ value shows in the multiple regressions was 0.742 , while the corresponding F-value was 23.74 and also significant at 0.001 levels which confirmed the fitness of the regression model. The findings of multiple regression analysis indicates that the determinant factors for creating farmers' access to ICT based media were availability of ICTs, Knowledge on ICT and Training received on ICT. This adjusted $\mathrm{R}^{2}$ value indicates that, three explanatory variables jointly can explain 74\% variations in the extent of farmers' access to ICT based media in receiving agricultural information. In addition to understand individual contribution of the aforesaid explanatory variables a step-wise multiple regressions analysis was conducted and the results are shown in Table 6.

Data presented in Table 6 indicates that availability of ICTs is the important factor for creating farmers' access to ICT based media. The findings of the multiple regression analysis indicates that availability of ICTs was significant and showed a positive trend, it implies that the probability of access to ICT based media increases with increasing the availability of ICTs of the respondents and therefore if appropriately used it can offer huge scope for development in the local area. Knowledge on ICT is also the important factor of access to ICT based media by the farmers. The findings of the step-wise multiple regression analysis indicates that knowledge on ICT was significant and showed a positive trend, it implies that the probability of access to ICT based media increases with increasing knowledge on ICT of the respondents. Some basic ICT knowledge such as uses of cell phone, smart phone, internet, computer etc. for getting agricultural information expected to increase access to ICT based media. A study of Khan [17] in his study showed that knowledge on ICT has positive and significant contribution with the extent of effectiveness of AICC in receiving agricultural information. It is very natural that resource rich farmers receives agricultural information by using smart phone while they learnt it from their respective AICCs. A good number of studies indicates the similar findings of $[18,19,20]$. The findings of the step-wise multiple regression analysis indicates that training received on ICT was significant and showed a positive trend, it implies that the probability of access to ICT based media may be increased with increasing training facilities for the farmers on ICTs. It can be interpreted in a way that farmer who will receive training will have more interest and try to collect timely and credible agricultural information using ICT based media.

\subsection{Problems Faced by the Farmers in Receiving Information from ICT Based Media}

To identify the problems faced by the farmers in receiving agricultural information using ICT based media a focus group discussion (FGD) was conducted. After getting the problems they were incorporated into the questionnaire to know the extent of each of the problems faced by an individual farmer and data were presented in Table 7.

Data presented in Table 7 shows that majority (61.25\%) of the farmers mentioned that poor level of their education is the highest level problem to them for getting better access to ICT based media. While more than half (53.75\%) of the farmers had problem on lack of knowledge on ICT facilities. At the same time, two-third (7.5\%) of them had the highest problem on operation knowledge of computer. On the other hand, extreme majority of the farmers thought that social religious restriction is not a problem for them.

Table 5. Summary of the multiple regression analysis

\begin{tabular}{|c|c|c|c|c|c|}
\hline \multirow{2}{*}{ Explanatory variable } & \multicolumn{2}{|c|}{ Unstandardized Coefficients } & \multirow{2}{*}{$\begin{array}{c}\text { Standardized Coefficients } \\
\text { Beta }\end{array}$} & \multirow{2}{*}{$\mathrm{t}$} & \multirow{2}{*}{$\mathrm{B}$} \\
\hline & $\mathrm{B}$ & Std. Error & & & \\
\hline (Constant) & -2.503 & 1.247 & & -2.007 & .049 \\
\hline Age & -.020 & .035 & -.065 & -.556 & .580 \\
\hline Education & .082 & .046 & .127 & 1.789 & .078 \\
\hline Household size & .120 & .087 & .085 & 1.382 & .171 \\
\hline Farm size & .081 & .299 & .021 & .271 & .787 \\
\hline Annual family income & -.004 & .003 & -.087 & -1.092 & .279 \\
\hline Organizational participation & -.074 & .095 & -.058 & -.782 & .437 \\
\hline Farming experience & .037 & .038 & .128 & .988 & .327 \\
\hline Knowledge on ICT & .356 & .069 & .454 & 5.163 & .000 \\
\hline Training received on ICT & .646 & .280 & .153 & 2.306 & .024 \\
\hline Availability of ICTs & .703 & .124 & .450 & 5.673 & .000 \\
\hline \multicolumn{6}{|c|}{ Adjusted $R^{2}=.742 F$-value $=23.747$} \\
\hline
\end{tabular}

Table 6. Summary of the step-wise multiple regression analysis models

\begin{tabular}{|c|c|c|c|c|}
\hline Variables entered into Model & Multiple $\mathrm{R}^{2}$ & Adjusted $\mathrm{R}^{2}$ & Variation explained (percent) & Significance level \\
\hline Availability of ICTs & .623 & .618 & 61.8 & .000 \\
\hline Knowledge on ICT & .737 & .730 & 11.2 & .000 \\
\hline Training received on ICT & .754 & .744 & 1.4 & .000 \\
\hline
\end{tabular}


Table 7. Problems faced by them farmers in receiving agricultural information from ICT based media

\begin{tabular}{|c|l|c|c|c|c|c|}
\hline \multirow{2}{*}{ SI. No. } & \multirow{2}{*}{ Problems } & \multicolumn{4}{|c|}{ Extent of problems } & \multirow{2}{*}{ PFI } \\
\cline { 3 - 6 } & & High & Medium & Low & NAA & \\
\hline 1 & Poor level of education & $49(61.25)$ & $31(38.75)$ & $0(0)$ & $0(0)$ & 209 \\
\hline 2 & Lack of knowledge on availability of ICT facilities & $43(53.75)$ & $34(42.5)$ & $3(3.75)$ & $0(0)$ & 200 \\
\hline 3 & Lack of operational knowledge of computer & $54(67.5)$ & $25(31.25)$ & $1(1.25)$ & $0(0)$ & 213 \\
\hline 4 & Social \& religious restriction & $0(0)$ & $1(1.25)$ & $8(10)$ & $71(88.75)$ & 9 \\
\hline 5 & Limited number of ICT centre & $45(56.25)$ & $33(41.25)$ & $1(1.25)$ & $1(1.25)$ & 202 \\
\hline 6 & High cost of internet service & $13(16.25)$ & $57(72.25)$ & $10(12.5)$ & $0(0)$ & 163 \\
\hline 7 & Lack of personal interest & $46(57.5)$ & $26(32.5)$ & $5(6.25)$ & $3(3.75)$ & 195 \\
\hline 8 & Low bandwidth speed of internet & $22(27.5)$ & $42(52.5)$ & $16(20)$ & $0(0)$ & 166 \\
\hline 9 & Lack of ICT software & $21(26.25)$ & $43(53.75)$ & $16(20)$ & $0(0)$ & 165 \\
\hline 10 & Electricity problem & $42(52.5)$ & $37(46.25)$ & $1(1.25)$ & $0(0)$ & 201 \\
\hline 11 & Lack of training facilities & $50(62.5)$ & $24(30)$ & $6(7.5)$ & $0(0)$ & 204 \\
\hline
\end{tabular}

[Number in the parentheses indicate percentage of the farmers].

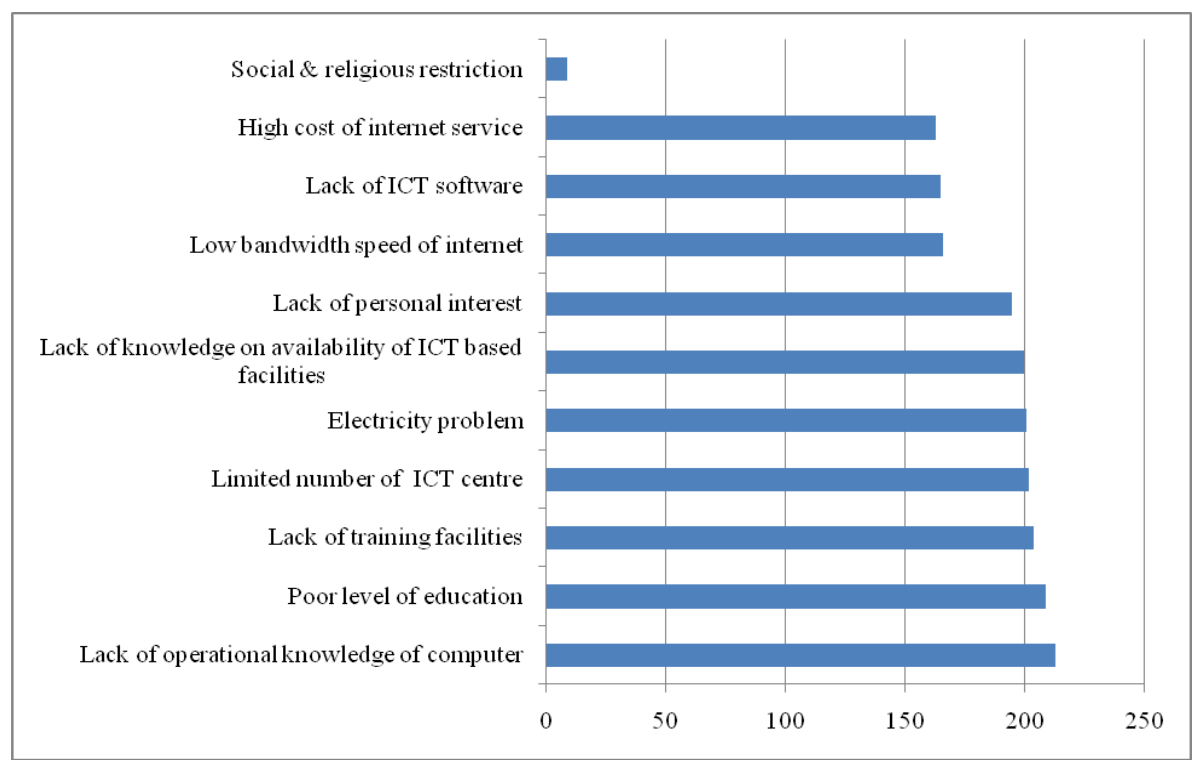

Figure 4. Rank order of the selected problems faced by the farmers in receiving agricultural information

While more than half of the farmers had high level problem of limited number of ICT centre in the locality as well as lack of their personal interest. While, majority $(72 \%)$ of them mentioned that higher price of internet services medium level problem to them. At the same time, more than half $(53 \%)$ mentioned low bandwidth of internet and scarcity of ICT software as medium level problem. Conversely, more than half of the farmers felt electricity problem and lack of training on ICT as the high level problem. In addition to explore the problems, a Problem Facing Index (PFI) was used to rank order the identified problems based on their severity and shown in Figure 4 indicates that the farmers were faced eleven (11) types of problems in receiving agricultural information from ICT based media. It is evident from Figure 4 that the "lack of operational knowledge of computer" is a great problem and accordingly it ranked first.

Farmers' poor level of education, lack of training on ICT and limited number of ICT centre ranked $2^{\text {nd }}, 3 \mathrm{rd}$, and $4^{\text {th }}$ position respectively based on their problem facing index score. While social and religious restrictions of the farmers ranked as least $\left(11^{\text {th }}\right)$ problem based on problem facing index(PFI) score. It is true that most of the farmers did not have any training on ICT for this reason they have very low operational knowledge of computer. So, the farmers thought that "lack of of training facilities" was another problem and it was ranked 3rd position. The forth problem was Lack of ICT centre and it was another serious problem.

\section{Conclusions}

In the time of globalization demand for ICTs have been increasing by the people of the different professions. It is revealed from the study that majority of the farmers had low access to ICT based media. This is evident from the study that most of the farmers had small farm size and they did not have adequate money to afford internet and other ICT based media for receiving agricultural information. The study showed that education, organizational participation, knowledge on ICT, training received on ICT and availability of ICTs had positive significant relationships with farmers' on access to ICT based media. Among the significant variables availability of ICTs, knowledge on ICT and training received on ICT were found influential for creating farmers' access to ICT based media for receiving agricultural information. So, it leads to be concluded that to increase farmers' access to ICT based media all of these factors should be keep in mind by the agricultural and rural development service provider GOs and NGOs. At the same times it is mandatory to take care the problems 
like lack of operational knowledge of computer, poor level of education, lack of training facilities, lack of ICT centre, electricity problem, lack of knowledge on availability of ICT based facilities, lack of personal interest, low bandwidth speed of internet, lack of ICT software, high cost of service, social \& religious restrictions those are faced by the farmers in using ICT based for getting agricultural information. Finally it can be concluded that ICT based media has tremendous effect in delivering timely and need based agricultural information to the farming community and in case of rural Bangladesh it demands special attention to create adequate access of the farmers to harvest this utmost benefits of ICT based media.

\section{References}

[1] BBS, "Statistical Yearbook of Bangladesh". Statistics Division, Ministry of Planning, Government of the People's Republic of Bangladesh, July 2015.

[2] Feed the Future, "Bangladesh: Desk Study of the Extension and Advisory Services", Developing Local Extension Capacity (DLEC)Project, March 2017. Available at, http://www.digitalgreen.org/wpcontent/ploads/2017/69/Bangladesh-Desk-study.pdf.

[3] Sarker, M.A. and Itohara, Y, "Information Sources Used by the Farmers Regarding Practice of Organic Farming-A Study from Bangladesh". Journal of Rural Problems, 43(1), 234-239. Jun 2007.

[4] Moon, S.J., Miah, M.A.M. and Berg, T, "Farmers' Awareness on Effective Delivery of Farm Information through ICT Mediated Extension Service in Bangladesh". European Scientific Journal, 12(21), 9-17.Jul 2016.

[5] Murithi, A.G., Bett, E. and Ogaleh, S.A, "Information Technology for Agriculture and Rural Development in Africa: Experiences from Kenya". Paper Presented in Conference on International Research on FoodSecurity, Natural Resource Management and Rural Development, University of Humburg, October 6-8, 2009.

[6] Akbar, M.S.U, "e-Krishok: Making ICT Work for Farmers A360Degree ICT Enabled Solution to Empower Farmers", Information and Communication Technologies for Agriculture and Rural Development (Second Edition), FAO, Regional Office for Asia and the Pacific, Bangkok, 2017.

[7] Selwyn, N, "Defining the ÔDigital DivideÕ: Developing a Theoretical Understanding of Inequalities in the Information Age, Jan 2002. Available at:

http://www.cf.ac.uk/socsi/ict/definigdigitaldivide.pdf. Henri Theil, Introduction to Economics, Prentice-Hall, Inc., Englewood Cliffs, N.J., 1978, p. 135.
[8] Crowder, L.V, "Knowledge and Information for Food SecurityThe Role of Telecentres. Seminar on Multipurpose Community Telecentres, Budapest, 7-9 December 1998. pp.2-9.

[9] Agricultural Information Service (AIS), "Agricultural Information and Communication Centre (AICC)". Agricultural Information Services, Ministry of Agriculture, Government of the People's republic of Bangladesh, November 2017. Available at, http://www.ais.gov.bd/site/page/b753abe5-5ef6-4c81-b0dc4eac331e9720/এআইসিসি.

[10] Kashem, M.A., Farouque, M.A.A., Ahmed, G.M.F. and Bilkis, S.E., "The Complementary Roles of Information and Communication Technology in Bangladesh Agriculture". Journal of Science Foundation, 8(1\&2), 161-169. Dec 2010.

[11] Swanson, B.E. and Rajalahti, R, "Strengthening Agricultural Extension and Advisory Systems: Procedures for Assessing, Transforming, and Evaluating Extension Systems". Agriculture and Rural Development Paper 45. World Bank, Washington, DC 20433, USA, 2010.

[12] DAE, "National Agricultural Extension Policy (NAEP)". Department of Agricultural Extension, Ministry of Agriculture, Government of the People's Republic of Bangladesh, July 2012.

[13] Asian Development Bank (ADB), "A Strategic Approach to Information and Communication Technology toward e-Development in Asia and the pacific". AND November, 2003.

[14] Meera, S.N, "A Critical Analysis of Information Technology in Agricultural Development: Impact and Implications". Unpublished PhD thesis, IARI, New Delhi. Jun 2003.

[15] Madukwe, M. C, "Delivery of Agricultural Extension Services to Farmers in Developing Countries; Issues for Considerations". Knowledge for development- Observatory on Science and Technology. Apr 2006. Available at, http//knowledge cta.int/tr/content/view/full/3009.

[16] Asif, M.A.S, "Use of Mobile Phone by the Farmers in Receiving Information on Vegetable Cultivation" (unpublished master's thesis). Department of Agricultural Extension Education, Bangladesh Agricultural University, Mymensingh. June, 2016.

[17] Khan, S, "Effectiveness of AICC in technology transfer as perceived by the farmers".(unpublished master's thesis). Department of Agricultural Extension Education, Bangladesh Agricultural University, Mymensingh. Dec 2016.

[18] Uddin, M. N., Bokelmann, W. and Entsminger, J. S, "Factors Affecting Farmers' Adaptation Strategies to Environmental Degradation and Climate Change Effects: A Farm Level Study in Bangladesh". Climate. 2, 223-241; Sep 2014.

[19] Nhemachena, C. and Hassan, R.H, "Micro-Level Analysis of Farmers' Adaptation to Climate Change in Southern Africa", IFPRI Discussion Paper No. 00714; International Food Policy Research Institute: Washington, DC, USA, August 2007. Available online: http://ageconsearch.umn.edu/handle/42399.

[20] Kim, C., Jung, H., Lee, S., Park, S. and Takei, A, "An Analysis on Determinants of Farmers' Adaptation to Climate Change in Korea”. Journal of Rural Development, 35, 53-72. 2012. 